\title{
Elite Rivalry: Government and Philanthropy in Israel
}

\author{
Uzi Sasson \\ Beit Berl College, Kfar Saba, Israel \\ Email: uzi.sasson@gmail.com
}

Received 25 January 2015; accepted 9 February 2015; published 13 February 2015

Copyright (C) 2015 by author and OALib.

This work is licensed under the Creative Commons Attribution International License (CC BY). http://creativecommons.org/licenses/by/4.0/

(c) †) Open Access

\section{Abstract}

Philanthropies and governments are two separate entities that distribute resources. Each sector uses a different set of criteria in deciding what to promote. Philanthropy is usually aimed toward doing good deeds, such as fighting poverty, helping the underprivileged, and other local or global problems. The government is a system that prioritizes the allocation of public resources. However, when it comes to private endeavors, governments would force private people to make donations or decide in which direction to channel these resources. Nevertheless, philanthropic charity in Israel is a phenomenon that raises issues of power and control between philanthropies and the government regarding the motives for giving and the goals of the enterprises supported. Hence, it is interesting to question the effects of the donations, the motivations for giving, and the influence it has on the Israeli society.

\section{Keywords}

Philanthropy, Israel, Government

Subject Areas: Business Ethics and Corporate Social Responsibility, Sociology

\section{Introduction}

Philanthropies and governments are two separate entities that distribute resources. Each sector uses a different set of criteria in deciding what to promote. Philanthropy is usually aimed toward doing good deeds, such as fighting poverty, helping the underprivileged, or other local or global problems. For example, Ashoka Foundation has invested more than 300 Million Dollars in social projects around the world. Skoll Foundation, established in 1999, has supported more than 60 social entrepreneurs by donating 200 Million dollars thus far. A government is a system that prioritizes the allocation of public resources. However, when it comes to private endeavors, governments cannot force private people to make donations or decide in which direction to channel these resources. 
In Israel, Philanthropy is part of the third sector landscape in Israel, and wealthy people do give a portion of their private resources for the use of the public. Nevertheless, philanthropic charity in Israel is a phenomenon that raises issues of power and control between philanthropies and the government regarding the motives for giving and the goals of the enterprises supported. Hence, it is interesting to question the effects of the donations, the motivations for giving, and the influence it has on the Israeli society

\section{The Electoral System in Israel}

As in any democratic country, the government is committed to the rule of law. However, in Israel the decisions of the government are very much determined by the electoral system in Israel, according to which, the number of mandates given to each party is proportional to the number of votes it receives in the elections. For example a party which receives $20 \%$ votes will receive $20 \%$ of Knesset mandates and its members will man $20 \%$ of the Knesset's 120 positions. Because the qualifying threshold that enables a party to enter the parliament is $2 \%$, representatives from many small political parties form the Israeli Knesset. The chair of the party who won the highest number of votes has to form a government by cooperating with other parties. Only if he is able to create a coalition of parties whose total number of mandates exceeds 61 will he be the Prime Minister.

The formation of a coalitional government involves power relations between the parties of the coalition. These are often characterized by a give and take approach which basically means that in return for participating in the coalition, the chair of the party that received the highest number of seats compensates the sector represented by the small party. This compensation has many manifestations. For example: in the 2009 elections, Shas, an ultra-orthodox religious political party in Israel, won 11 mandates, and in return for joining Benjamin Netanyahu's coalition government, it was paid four cabinet posts. These changes and instability in the structure of governments dictate how resources are allocated in Israel. When a party is badly needed to reach a coalition of 61 mandates, it will be given more ministerial portfolios than it deserves, and the ministers who chair the main offices in the government promote the interests of the sector which voted for them.

\section{The New Israeli Fund}

Opposing forces which have a different ideology in regards to how resources should be distributed use charity philanthropy to influence the public. The New Israel Fund, which is a foundation centered mostly in the U.S, is one example as it funds political related projects in Israel. One such project is the social protest that took place in the summer of 2011 in Israel, (Wikipedia.org) [1]. The Fund is registered as a 501(C) (3) (nonprofit organization) since 1979 in Washington, DC. (Guidestar.org) [2], and has centers in New York, Florida, Kansas, Maryland, Michigan, Mississippi, New Jersey, North Carolina, Pennsylvania, Virginia, West Virginia (NIF.org) [3]. In addition, it is registered as a nonprofit organization in Israel since 1992, and in Canada, U.K. and Swiss where it keeps local centers (Wikipedia.org) [1]. The New Israel Fund asks to dismantle the foundation registration as from 2012 in Israel. Nevertheless, its fiscal activities reported in 2009 the American IRS reflected contributions and grants of $\sim \$ 26.5 \mathrm{M}$ and $\sim \$ 34 \mathrm{M}$ in the year of 2008 (form 990, IRS 2009). It declares (NIF.org) [3] that it provided “more than $\$ 200$ Million to more than 800 cutting-edge organizations".

The New Israel Fund's vision is to "ensures complete equality so social and political rights to all its inhabitants irrespective of religion, race or sex" (NIF.org) [3]. Accordingly, The New Israel Fund actively supports, through funding and advocacy, hundreds of organizations that are considered by the foundation as leaders which promote equality and democracy in Israel. Some of these organizations have a "left-wing" orientation and actively produce reports, demonstration, advocacy, and other activities toward the promotion of their "left-wing" policy against the "right-wing" Israeli government. For instance, The New Israel Fund (NIF.org) [3] funds "Adalah [4] which is a legal center for Arab minority rights in Israel" (NIF.org) [3]. It also supports "Breaking the Silence" [5] that aims at "Raising Public awareness about the moral dilemmas faced by soldiers serving in the occupied territories by collecting and publishing soldiers' testimonies, public events and advocacy" (NIF.org) [3]. An additional organization is SHATIL, which "promotes democracy, tolerance, and social justice in Israel", and work with organizations that "promote Jewish-Arab equality and coexistence, foster tolerance and pluralism, and encourage government accountability" (NIF.org) [3].

Although, all institutions listed under The New Israel Fund (i.e., Adalah [4], Breaking the Silence [5], etc') are legitimate in under the premises of a democratic regime, the activities of these organizations are considered provocative for a "right-wing" government. For instance, Adalah [4] proposed, in 2007, a "democratic constitu- 
tion” for Israel which should replace the Jewish fundamentalism of the state of Israel (Adalah.org) [4]. In September, $16^{\text {th }}$, 2009, the organization published "News Update", in which Adalah [4] declares itself as a "Palestinian human rights organization" (Adalah.org) [4], and demands foreign governments to "re-evaluate their relationship with Israel" because Israel is accused by Adalah [4] of committing "crimes against humanity" (Adalah.org) [4].

The image of "Breaking the Silence" [5] in the Israeli society is of a "left wing" group which provokes the law and order of the Israeli police in the city of Hevron. "Breaking the Silence" [5] promotes tours that are considered by police authorities dangerous to the police forces. Shai, a senior District Police official told Ynet [6] on June $18^{\text {th }}, 2008$ that "The activity of some leftist organizations in Hebron is more dangerous that which is being conducted by their right-wing counterparts”. An article in Maariv [7] newspaper commented on July $7^{\text {th }}$, 2009 that the soldiers' testimonies as published by the organization damage Israel defense forces (i.e. IDF) and only portray the IDF as a violent force which aims to abuse the Palestinian society.

In addition, The New Israel Fund is known for its support for Goldstone report to the UN in September 2009. The report was a turning point in the relationship between foreign governments and the Israeli state. The report was considered to be a "diplomatic Tsunami" for Israel, while countries such as India and China supported the report. As opposed to that, The New Israel Fund identifies with the damage the report has caused (Maariv, January $\left.30^{\text {th }}, 2010\right)[7]$.

Usually, philanthropic ventures involve social intervention, which position them closely as a substitute for the government and as a power structure that is expected to solve problems. In this context it is noteworthy to mention that the New Israel Fund supported the demonstrations during spring of 2011. The upraising in Israel was recognized with the "middle class" expressing the disappointment from the economic hardship people suffer in Israel. The upraising was also known as the protest for social justice. Although the demonstrators demanded reasonable prices for housing, basic consumption products, and a discount for government services such as education and healthcare, the slogans called for a change of government.

The demonstrations involved hundreds of thousands of people who joined parades around major cities in Israel. The biggest demonstration took place in Tel-Aviv, while other demonstrations were in Haifa, Jerusalem, and Beer-Sheva. They mainly paraded during Saturday night, but during weekdays, the hardcore of the demonstrators were camping in major streets, sleeping in tents and having lectures and activities educating them how to shape their demands and what kind of solution to look for while in the camp.

In response to the demonstrations and the street activities, the government consulted Prof. Trachtenberg who advised for possible solutions to meet the demands. Prof. Trachtenberg advices were partly accepted. The main protestors' demand was to lower the high housing prices, and indeed, resulted from Prof. Trachtenberg's report [8], the government voted for a new housing plan. The plan includes expediting the building licensing, incentives for contractors who increase the number of student apartments and public transportations discounts for students who live far from the university campus, so they can seek cheaper housing in rural areas.

The Israeli government considers a number of "left-wing" foundations as the driving force of the demonstrations. The government accused the leaders of acting in the name of political change rather than economic reform. The demonstrations anonymously called for replacing the Prime Minister and the government he leads. Officials pointed out that Dafnie Leaf, who initiated the protest and led it, was a former New Israeli Fund's employer and therefore adopted the fund's leftist ideology. They further pointed out on the organizations that joined the protesters and supported the demonstrators (i.e. Shatil [8], Adam Teva v'din [9], and others).

Nevertheless, The New Israel Fund was not alone in supporting the uprising of Israelis against the government. An additional philanthropist, such as Daniel Abraham, the founder of "Slim Fast" was one of the major economic engines who fueled the protest. Abraham explained (Nana.co.il) [10] that he decided to support the demonstrations because they call for stopping financial government support to the settlements and ultra-orthodox Jews, as part of the national fiscal budget. Mr. Abraham identifies himself as a left-wing political opinionated activist, who believes that finding a solution to the Israeli-Palestinian conflict will eventually result in economic relief. He funds the center for peace in the Middle-East, and donates to the left wing political rallies (News Channel 10) [11].

To sum up this subsection, these arguments and examples, written above, heighten our understanding in regards to philanthropy's motivations to contribute resources, fund the front line organizations, and get involved in political matters. Further in the paper I sort out the reasons that local people, and groups living abroad, get involved politically and make philanthropic donations for the benefit of the Israeli public. Researchers have long 
claimed that philanthropic activities involve more than just doing purely good. Rather, their motivation is a mix of two desires: generating power and in actively pursuing individual goals and aspirations in Israel.

Fleishman (2007) [12] questions foundations' motivations in his book "The Foundation". For the simple question "why they give?" Fleishman (2007) [12] lists 6 of the most frequent motivations. He notes that foundations' motivation to give fall between the two ideal types: being "purely altruistic" and "self serving". Accordingly, giving an organization or a project from a purely altruistic position motivated expresses a value connected to the contributor's believe. Some common examples are giving to a school that the contributor graduated from, a hospital that gives medical care for a specific society, or even a religious program, that the contributor identifies with (Fleishman, 2007) [12]. Under giving for "self serving” purposes, Fleishman (2007) [12] lists: serving the contributor's ego, or the desire to pursue a positive public image of himself. The latter reflects a motivation concerning a social aspect of the contributor's relations with his colleagues or other important people.

\section{Elite Theory}

A key "self serving” purpose is the ambition to strive for more power (Parry, 1989 [13]; Dees 2008 [14]). Striving for power is a characteristic of individuals, organizations and elites too. This motivation is central in Israel which has a strong military elite. This elite largely controls the decision making in the parliament, the government and the civil society.

Elite is an institution which selects its members carefully. Entering the elite is not easy as the power of the elite is in many ways reflected by its capacity to dictate the terms for entering its space. Fundamentally, conformity to standards of wealth, social background, educational attainment and commitment to the elite's interests and ideology are the basis premises of passing the gates of the group.

The high turnover volume of officers in the IDF expands the military elite in Israel. IDF's senior officers occupy positions in all sectors of the Israeli society and not only positions that are related to their previous experiences. These military past and present member have access to all sorts of power centers that control the country's most influential bodies. To illustrate, major-general Yeftach Ron-Tal, is the chairman of Israel Ports. Israel Port is responsible for 98\% of the seaports of the country's import and export cargo (Israel Ports) [15]. Majorgeneral Amiaz Sagis, who served the IDF for 32 years, was appointed in 1998 to the CEO of SuperSal groceries chain. Major-general Udi Adam became the general manager of the Negev Nuclear Research Center. Majorgeneral Avital Rapaport occupies the Ministry of the Environment in Israel. Major-general Yaakov Even filled the position of the chairman of the National Coal Company. Major-general Gabi Ofir is the CEO of the Israel Airport Authority. Major-general Yizchak Chophie becomes the CEO of The Electricity Company.

The above examples are indications to the power the military group has in Israel. According to Lukes (2005) [16], Foucault (1979) [17], Parry (1989) [13], and Kaplan and Grossman (2010) [18], this group of former military personnel has the power and influence which is a key factor in defining it as elite. Elite is defined Parry (1989) [13], Kaplan and Grossman (2010) [18] and Nicholls (2010) [19] as a group of people who are powerful enough to act and set norms according to their own values and logic.

In the Israeli case, the military elite has more power than the economic elite. The economic elite, therefore, tries to gain power against the other elites in this zero sum game. Military elite tend to rule continually so to be able to provide more benefits and resources to its members which means obtaining social wealth, economic influence, social status, and educational advantages (Parry, 1989) [13]. In addition, military elites control the power in a way that prevents other social groups from provoking the dominance of the military's leadership and becoming a meaningful force in decision making processes (Parry, 1989) [13].

According to this operational definition, philanthropy can be defines as an economic elite in Israel. Philanthropies, according to Anheier and Leat (2006) [20], act strategically upon their ventures to pursue their goals and values. They take the role of being efficient actors by aligning the key discourses and norms in the field of operation. Therefore, elites are considered to be a threat to democracies (Parry, 1989) [13]. They intervene in decision making using their direct connections to government officials. This access empowers the elite while officials, who hold key positions, sometimes cannot act for the best of society, because their decision making process is affected by elite interests (Parry, 1989) [13].

Economic elite endangers society since it usually controls mass communication and other channels of information (Parry, 1989) [13]. For example, Nochi Dankner, the owner of I.D.B. group, which is worth around 80 billion NIS is one of the 100 wealthiest figures in Israel (Maariv, 2010) [7]. According to the "Globes" newspa- 
per (March, 2011) [21], I.D.B invested 120 million NIS and assumed control (59\% of Maariv stokes) over Maariv newspaper. Dankner was only one of 9 people who, according to TheMarker.com [21], exercised his power over politics, law-makers and mass-communication. The other 8 people, according to TheMarker.com [21], are Noni Moses, Sheldon Aldson, Yitzhak Tshuva, Zadik Bino, Haim Saban, Muzi Wertheim, Eliezer Fishman, and Yossi Maimann.

TheMarker.com [21] argues that the power and economic strength that very wealthy people have often translates to political power. The political power they gain enables them to override democracy and the rule of law, and therefore influence regulations while restricting the Israeli market to perform on their benefit. They gain enormous political power in Israel, argues TheMarker.com [21], using donations to politicians, and recruiting former politicians as chairmen of companies they control. Philanthropists in Israel lead politicians in power to believe that they will have the opportunity to hold a chairman position in one of their companies in the future. For that reason, politicians heavily advocate for philanthropists' benefit. On the other side, philanthropists spend a fortune on public relations by controlling mass-communications channels, and recruiting former regulators to oppose the once in duty. To illuminate, Dankner controls tens of thousands of jobs in the Israeli market influencing the everyday life of almost every citizen in Israel, who uses a mobile phone, purchases an apartment, or buying vacation deal (TheMarker.com) [21].

Many philanthropists indeed control the Israeli media. For example, Moses who controls Yediot Acharonot newspaper, also holds $17 \%$ of HOT-Cable company and the Russian language newspaper Vesti. In addition, Moses controls 50\% of Ynet and ONE, an internet newspaper. The power Moses has under his hands enables him to be a threat to politicians. Not using the power is a strategy that exercises his power. TheMarker [21] claims that Moses uses this strategy and promotes his interests by directing his media tools to avoid criticizing the Minister of communications since he serves the overall interests of Moses. Furthermore, Tami Moses, Noni Moses' sister, is closely connected with Raffi Ginat, who became the editor of Yediot Acharonot Newspaper. Noni's sister, Judy Moses married the Minister and the Deputy to the Israeli Prime-Minister, Silvan Shalom (TheMarker.com) [21].

Eliezer Fishman, according to TheMarker.com [21], has 38\% of Yediot Acharonot newspaper, 66\% of Globs newspaper, and $14.6 \%$ of HOT cable television. Fishman appointed the ex-regulator-Yoram Mokdie, to be the deputy director of regulation in HOT, and Ram Belishnikov, who was the senior director of HOT appointed to the director of budget division of the Ministry of finance.

Yossi Maimann himself is an Israeli patriot who, according to TheMarker.com [21], involved in espionage for Israel, while in South Africa. Maimann established Channel 10 in Israel and one of the partners of EMG which delivers natural gas from Egypt to Israel. Maimann recruited the former Foreign Israeli intelligent DirectorShabtay Shavit, as a consultant during 2004. Maimann's senior employee, Raffi Peled, became the chief of staff in the Israeli Prime Minister office.

Another powerful individual is Yitzhak Tshuva, who according to TheMarker.com [21], employs ex-regulators, ex-IDF's senior officers and senior bankers in his companies. Tshuva's estimated wealth is about \$2.6 - 2.2 Billion NIS, and he mainly controls Delek, a fuel Group with 59\% and HOT with 16\%. The Delek Group's CEO is Eyal Lapidot, who was the comptroller advisor at the Ministry of finance. The CEO of IDO, a major desalination company, is Avshalom Plaber, who served as deputy director of the budget division in the Ministry of finance, and the ex-director of the Ministry of finance, Prof. Ben-Zion is the chairman of Delek Group.

Sheldon Aldson, one of the utmost rich Jewish people in the world, has recently established the free newspaper IsraelToday. Soon, the circulation of the newspaper became second to the highest influential newspapers in Israel with a volume of 255,000 copies per day (TheMarker.com) [21]. The newspaper promotes the "left-wing" ideology and in 2008 the New Yorker published an interview with Aldson and claimed that one of the purposes of establishing the newspaper was the impeachment of the Israeli Prime Minister Ehud Olmert. TheMarker.com [21] illuminates on the ties Aldson has with the present Prime Minister Netanyahu, and points out that the two first made their contact while Netanyahu served as Israel Ambassador to NATO.

Two other powerful persons who play a central role in the Israeli banking system are Zadik Bino and Muzi Wertheim. In 2003, Zadik Bino, purchased the International Bank in Israel, the Masad Bank, and Bank Otzar La'chayal. He became the chairman of the International Bank credit Committee, which automatically gave him the ability to assess the conditions of the primary borrowers of the Israeli market and that leverages his businesses (TheMarker.com) [21]. Muzi Wertheim, who controls 20\% of Bank Hamizrachi Tephachot, and 51\% of Keshet Communication Company, donate 36,000 NIS to Ehud Barak's primaries in 2007, and 54,000 NIS for 
the Avoda party in 1992. He also supported the former Internal secret services director-Yaakov Perry to become the chairman of Bank Mizrachi Tephachot (TheMarker.com) [21].

Though living in L.A, Haim Saban influences Israeli politics in more than one avenue. In 2002 he established the Saban Center for Policy in the Middle-East, and hosted Israeli ex-official personnel for a few months of training. For example, he hosted the reporters Nachum Barneah and Sever Pluzker from the Yediot Acharonot newspaper. Avi Dichter, has been hosted in the Saban Center prior to his appointment to the Minister of homeland security. According to TheMarker.com [21], Haim Saban purchased 30\% of the Israeli national telephone company-Bezeq, and Minister of communications, Dalya Itzik, used her power as a Minister to approve Saban's control over "Yes" (a cable company) and Keshet (a national T.V concessionaire) against the law because of a huge donation Saban made (TheMarker.com) [21].

\section{Conclusions}

In light of the above review, it seems that the military and the economic elites have competed against each other for public support, because, as Parry (1989) [13] argues, the legitimacy of the ruler is based on the principal of generating support from the majority. Furthermore, the rivalry between the economic and the military elite accumulates more power to both elites, since the presumption of the elite is that being in power grant the access to more power and resources (Parry, 1989) [13]. For example, the Minister of Defense has recently asked to use the financial reserves and add five more billion dollars to the security budget.

So, what does it all mean? What are the implications of this rivalry on the Israeli society? How do we limit the power of elites which take advantage of the public resources for the benefit of promoting their interests? The solution is standardizing philanthropic activities which will reduce the need of the military elite to execute the rule of law and over regulate philanthropy in Israel. At the same time, standards will enable wise and responsible investments, government and philanthropy cooperation, and effective allocation and use of funds. The military elite has its own agenda, but as the leader and governing entity, it has to rely on public opinion. Hence, the leadership's ideology should reflect the mass benefits, since preventing too much goods from the mass will ultimately bring the winds of protest. A fast growing economy that benefits only the leadership and the elite is the right recipe for the mass to rebel.

\section{References}

[1] Wikipedia.org http://en.wikipedia.org/

[2] Guidestar.org http://www.guidestar.org/

[3] NIF.org http://www.nif.org/

[4] Adalah.org http://www.adalah.org/

[5] Breaking the Silence http://www.breakingthesilence.org.il/

[6] Ynet http://www.ynet.co.il/home/0,7340,L-8,00.html

[7] Maariv http://www.nrg.co.il/

[8] Shatil http://www.shatil.org.il/

[9] Adam Teva v'din http://www.adamteva.org.il/

[10] Nana http://www.nana10.co.il/

[11] News Channel 10 http://news.nana10.co.il/Category/?CategoryID=300583

[12] Fleishman, J. (2009) The Foundation: A Great American Secret; How Private Wealth Is Changing the World. PublicAffairs, New York.

[13] Parry, J. (1989) On the Moral Perils of Exchange. In: Parry, J. and Bloch, M., Eds., Money and the Morality of Exchange, Cambridge University Press, Cambridge, 64-93. http://dx.doi.org/10.1017/CBO9780511621659.003

[14] Dees, J.G. (2008) Philanthropy and Enterprise: Harnessing the Power of Business and Social Entrepreneurship for Development. Innovations, 3, 119-132. http://dx.doi.org/10.1162/itgg.2008.3.3.119

[15] Israel Ports http://www.israports.org.il/Pages/HomePage.aspx

[16] Lukes, S. (2005) Power: A Radical View. 2nd Edition, Palgrave Macmillan, Basingstoke.

[17] Foucault, M. (Trans Hurley, R., et al.) (2002) Omnes et Singulatim. In: Faubion, J.D., Ed., Michel Foucault: Power Essential Works of Foucault 1954-1984, Vol. 3, Penguin, London, 298-325. 
[18] Kaplan, R.S. and Grossman, A.S. (2010) The Emerging Capital Market for Nonprofits. Harvard Business Review, 88, 110-118.

[19] Nicholls, A. (2010) The Legitimacy of Social Entrepreneurship: Reflexive Isomorphism in a Pre-Paradigmatic Field. Entrepreneurship Theory and Practice, 34, 611-633. http://dx.doi.org/10.1111/j.1540-6520.2010.00397.x

[20] Anheier, H. and Leat, D. (2006) Creative Philanthropy. Routledge, London.

[21] TheMarker.com http://www.themarker.com/ 
Scientific Research Publishing (SCIRP) is one of the largest Open Access journal publishers. It is currently publishing more than 200 open access, online, peer-reviewed journals covering a wide range of academic disciplines. SCIRP serves the worldwide academic communities and contributes to the progress and application of science with its publication.

Other selected journals from SCIRP are listed as below. Submit your manuscript to us via either submit@scirp.org or Online Submission Portal.
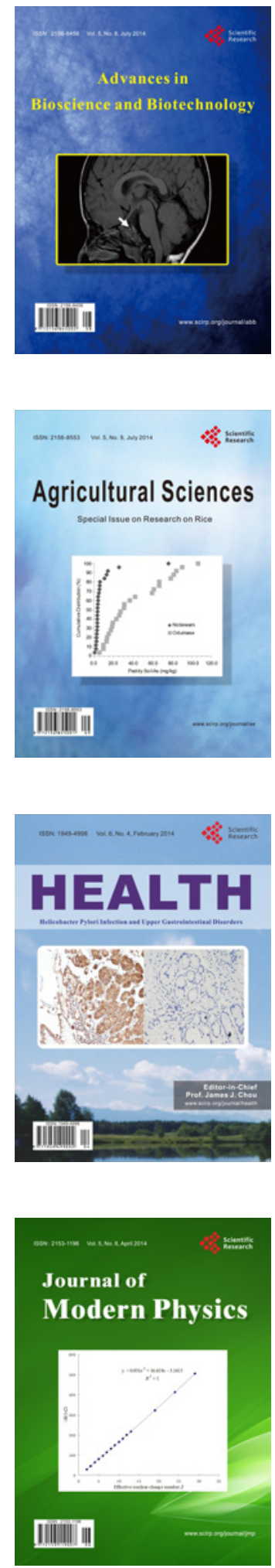
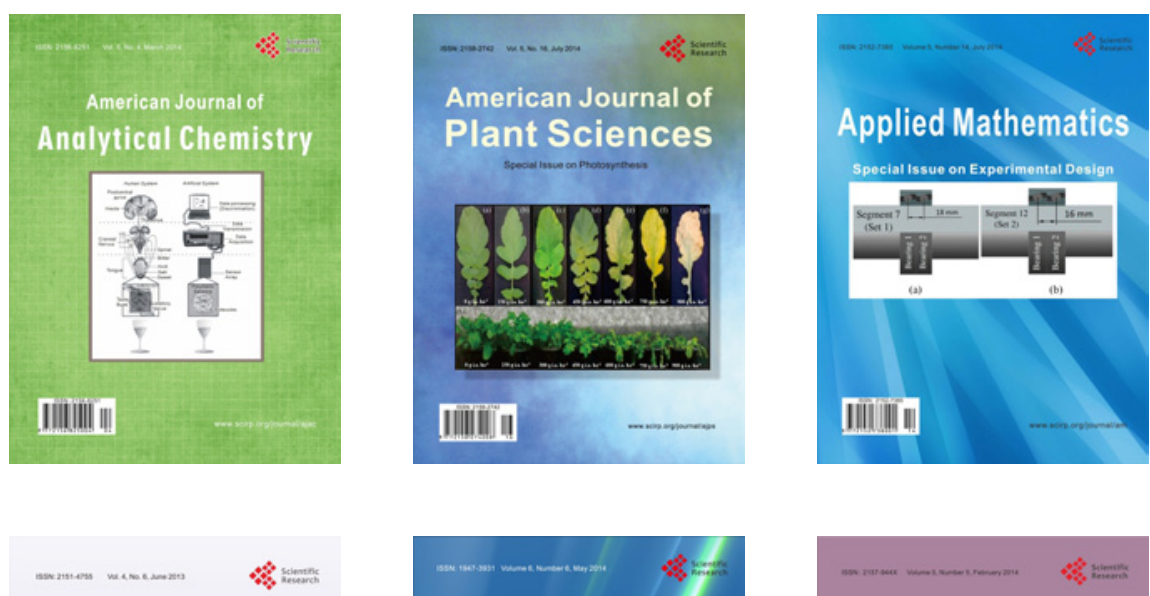

Creative Education
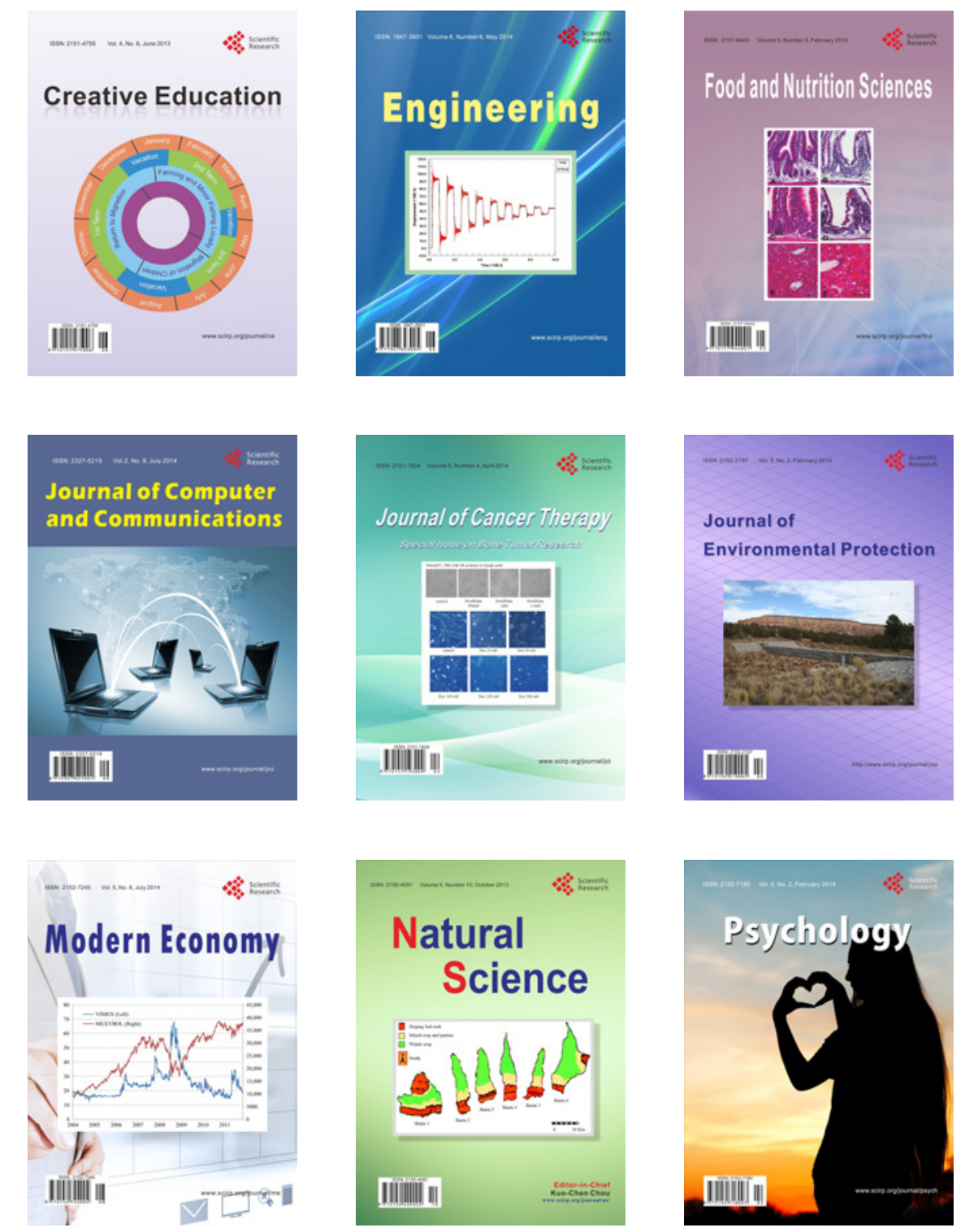